\title{
Laju Pertumbuhan dan Pertumbuhan Mutlak Karang Lunak Cladiella sp. pada Substrat yang Berbeda
}

\author{
Diah Putri Fitriani, Muhammad Zainuri dan Wahyu Andy Nugraha*
}

Jurusan Kelautan dan Perikanan, Fakultas Pertanian, Universitas Trunojoyo Madura, Jl. Raya Telang, Kamal, Bangkalan, 69162, Indonesia

Email: wahyuandy@trunojoyo.ac.id

\section{Abstract \\ Growth Rate and Total Growth of Soft Coral Cladiella sp. on Different Substrates}

Soft corals have a soft textured skeletal like tiny spikes made of calcium carbonate present in their tissues. In general, soft corals are attached to hard substrates in the bottom of the waters. This study aims to determine the survival rate, relative and absolute growth rate, and comparison of soft coral growth rates on different substrates. The survival rate obtained was 100\%, or 20 soft coral fragments lived until the end of the study. The growth rate and absolute growth of soft coral is relatively varied due to environmental and water quality, with the highest growth rate and absolute growth found in rubble substrate. week and $2,875 \mathrm{~cm} /$ week. There was no significant difference in growth rate of soft coral Cladiella sp. on the different substrate. In transplantation or soft coral cultivation activities, the selection of substrates becomes very important, and it is recommended to use rubble or dead coral substrates.

Keywords: Soft Coral; Cladiella sp.; Transplantation; Growth Rate

\begin{abstract}
Abstrak
Karang lunak mempunyai tekstur kerangka yang lunak berupa duri-duri kecil dari kalsium karbonat yang ada dalam jaringan tubuhnya. Pada umumnya karang lunak melekat pada substrat yang keras di dasar perairan. Penelitian ini bertujuan untuk mengetahui tingkat kelangsungan hidup, laju pertumbuhan relatif dan mutlak, dan perbandingan laju pertumbuhan karang lunak pada substrat yang berbeda. Tingkat kelangsungan hidup yang didapatkan yaitu $100 \%$ atau 20 fragmen karang lunak dapat hidup sampai akhir penelitian. Laju pertumbuhan karang lunak relatif bervariasi karena pengaruh lingkungan dan kualitas air. Laju pertumbuhan dan pertumbuhan mutlak karang lunak Cladiella sp. relatif bervariasi karena pengaruh perbedaan substrat yang berbeda, dengan laju pertumbuhan dan pertumbuhan mutlak tertinggi ditemukan pada substrat rubble. Tidak ada perbedaan yang nyata pada laju pertumbuhan karang lunak Cladiella sp. pada substrat yang berbeda. Pada kegiatan transplantasi ataupun budidaya karang lunak, pemilihan substrat menjadi sangat penting, dan disarankan untuk menggunakan substrat rubble atau karang mati.
\end{abstract}

Kata Kunci : Karang Lunak; Cladiella sp.; Transplantasi; Laju Pertumbuhan; Pertumbuhan

\section{PENDAHULUAN}

Karang lunak biasanya dijadikan karang hias di akuarium karena dilihat dari warna yang dimilikinya. Bentuknya yang menyerupai karang batu juga menjadi daya tarik sehingga banyak peminatnya. Knittweis and Wolff (2010), menyatakan bahwa
Indonesia merupakan negara terbesar yang mengeksport karang hias dengan jumlah mencapai $91 \%$. Melalui survey pendahuluan karang lunak yang hidup di daerah Desa Romben Guna Kecamatan Dungkek Kabupaten Sumenep didominasi karang lunak Cladiella sp. Daerah ini merupakan 
tempat pengambilan karang lunak hias. Oleh karena itu, menjadi tantangan sekaligus ancaman terhadap keberadaan karang lunak adalah pemanfaatannya untuk diperdagangkan sebagai karang hias.

Pada umumnya karang lunak melekat pada substrat yang keras di dasar perairan. Salah satu yang menjadi tempat menempelnya karang lunak yaitu pada karang yang telah mati. Larva karang lunak setelah mengalami fase planktonik akan mencari substrat yang kokoh untuk menempelkan diri, yang kemudian akan berkembang menjadi karang muda untuk terus hidup dan berkembang menjadi suatu ekosistem (Bachtiar et al., 2012).

Dengan adanya transplantasi karang lunak, diharapkan mengurangi kerusakan ekosistem terumbu karang di laut lepas. Penelitian tentang pertumbuhan karang lunak pernah dilakukan pada transplantasi karang lunak Lobophytum sp. pada subtrat semen (Subhan et al., 2012) dan rubble (Prastiwi et al., 2012) serta Sarchophyton sp. pada rak besi (Wijayanti et al., 2017). Akan tetapi, belum ada penelitian tentang pertumbuhan karang lunak pada berbagai jenis substrat yang berbeda. Informasi tentang perbedaan substrat penempel akan memberikan informasi jenis substrat yang baik untuk mengembangkan transplantasi dalam skala akuarium sehingga dapat membantu karang lunak Cladiella sp. tumbuh optimal, untuk itu penelitian ini perlu dilakukan. Cladiella sp. merupakan salah satu jenis karang lunak yang sering diperdagangkan, serta mempunyai potensi yang besar sebagai bahan obat karena mempunyai senyawa bioaktif (Rodrigues, 2019).

Penelitian ini bertujuan untuk mengetahui (1) persentase tingkat kelangsungan hidup karang lunak Cladiella sp. pada substrat yang berbeda, (2) laju pertumbuhan relatif dan pertumbuhan mutlak karang lunak Cladiella sp., dan (3) perbandingan laju pertumbuhan karang lunak Cladiella sp. pada substrat yang berbeda.

\section{MATERI DAN METODE}

Sampel karang lunak diambil dari daerah perairan Desa Romben Guna, Kecamatan Dungkek, Kabupaten Sumenep (Gambar 1). Lokasi pengambilan sampel karang terletak pada titik koordinat 06052' $965^{\prime \prime}$ LS dan 113000'735" BT.

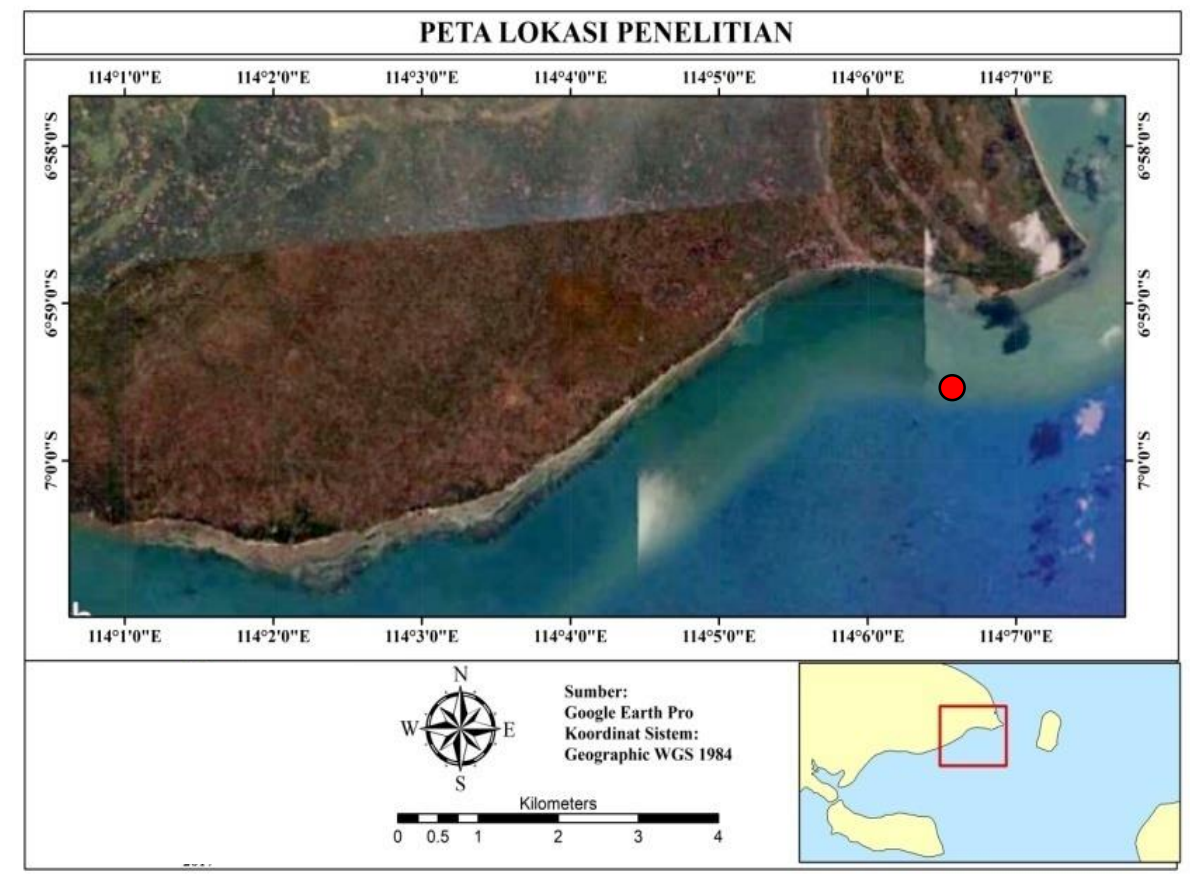

Gambar 1. Peta Lokasi Pengambilan Sampel Karang Lunak Cladiella sp. 


\section{Aklimatisasi Karang Lunak Cladiella sp.}

Sample karang lunak sebelum dimasukkan ke dalam akuarium, di rendam di akuarium terlebih dahulu tanpa membuka dari plastiknya. Hal ini bertujuan agar karang lunak menyamakan suhunya dengan air dalam akuarium. Sehingga, karang lunak lebih cepat beradaptasi dengan air dan lingkungan yang baru. Proses ini dilakukan selama lebih dari 3 jam.

Setelah kantong plastik yang berisi karang lunak direndam, kantong plastik dibuka satu persatu dan karang lunak di keluarkan lalu di letakkan secara perlahan di dasar akuarium. Biasanya respon yang dikeluarkan oleh karang lunak Cladiella sp. ketika mengalami stres, warnanya berubah menjadi putih ke abu-abuan dengan mengerutkan tubuhnya. Proses aklimatisasi ini membutuhkan waktu kurang lebih dua minggu (14 hari). Karena karang lunak akan dipotong sehingga, waktu aklimatisasi lama agar karang lunak benar-benar sehat kembali (Modifikasi dari Subhan et al., 2012; Wijayanti et al., 2017).

\section{Pemotongan dan Penempelan Karang Lunak Cladiella sp.}

Karang lunak Cladiella sp. yang sehat bisa langsung dipotong. Karang lunak yang dipotong pada saat penelitian dalam ukuran kisaran 1-2 cm. Ciri karang lunak Cladiella sp yang sehat yaitu warnanya coklat dan terlihat segar/tidak pucat. Pemotongan karang lunak menggunakan gunting. Hasil potongan karang lunak diikat dan ditempelkan pada substrat (media penempel) (Modifikasi dari Wijayanti et al., . 2017).

Pada penelitian ini menggunakan substrat/media tanam yang berbeda yaitu substrat karang mati, substrat semen, substrat keramik dan rubble. Dari keempat jenis substrat ini menggunakan jenis karakteristik yang hampir sama. Pada substrat karang mati berukuran kurang lebih diameter $10 \mathrm{~cm}$, substrat semen kurang lebih diameter $7 \mathrm{~cm}$, substrat keramik $5 \times 8 \mathrm{~cm}^{2}$ dan substrat rubble memiliki komposisi kerikil $45 \%$ dan pasir $55 \%$ (Gambar 2).
Proses aklimatisasi dilakukan kembali saat setelah karang sudah dipotong dan ditempel pada berbagai substrat/media dengan proses yang sama seperti aklimatisasi yang pertama.

\section{Pemberian Pakan}

Karang lunak makan melalui proses fotosintesis dengan bantuan zooxanthellae yang bersimbion dengan karang. Disamping itu karang lunak makan dengan cara menangkap organisme planktonik seperti larva krustasea dan larva moluska. Pada penelitian ini selain menggunakan lampu sebagai pengganti matahari juga menggunakan makanan tambahan/suplemen yang dijual di pasaran.

Pada penelitian ini menggunakan suplemen yang berguna untuk meningkatkan warna, pertumbuhan dan pemulihan luka. Suplemen ini mengandung 17 jenis asam amino, vit B kompleks, vit C, vit D dan synthetic growth factor yang dibutuhkan karang lunak sebagai pengganti pakan alami (Prastiwi et al., . 2012). Suplemen ini digunakan satu minggu satu kali dengan takaran 1 vial digunakan dalam 2 kali pemakaian. Dalam 1 vial memiliki berat $2 \mathrm{gr}$.

\section{Perlakuan dan Cara Pengukuran Karang Lunak Cladiella sp.}

Setiap perlakuan menggunakan 5 buah karang lunak, sehingga terdapat total 20 karang lunak yang dipakai dalam penelitian ini. Karang lunak diletakkan ke dalam akuarium secara acak memakai prinsip rancangan acak lengkap (RAL). Pengukuran karang lunak Cladiella sp. menggunakan jangka sorong yaitu secara vertikal (panjang) dan horizontal (lebar). Fragmen karang lunak diukur dari kapitulum terluar (Gambar 3).

Cara pengukurannya dengan melihat dari atas akuarium, jika terlihat kapitulum yang terluar. Maka, bagian tersebut yang menjadi bagian yang diukur menggunakan jangka sorong. Biasanya hal demikian dilakukan untuk mendapatkan nilai lebar. Dan untuk mendapatkan nilai panjang dengan cara melihat secara sejajar dari arah depan akuarium. Sehingga kapitulum yang 
terpanjang yang menjadi bagian yang diukur menggunakan jangka sorong. Pada pengukuran panjang diukur dari dasar bagian fragmen karang lunak yang

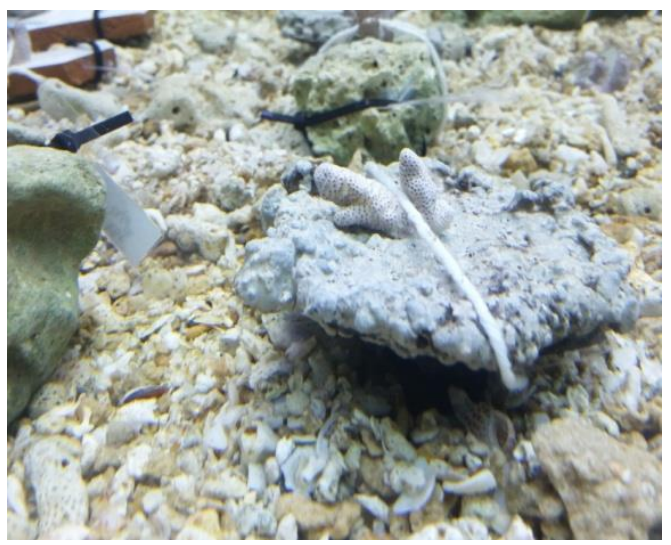

Substrat Batu Karang

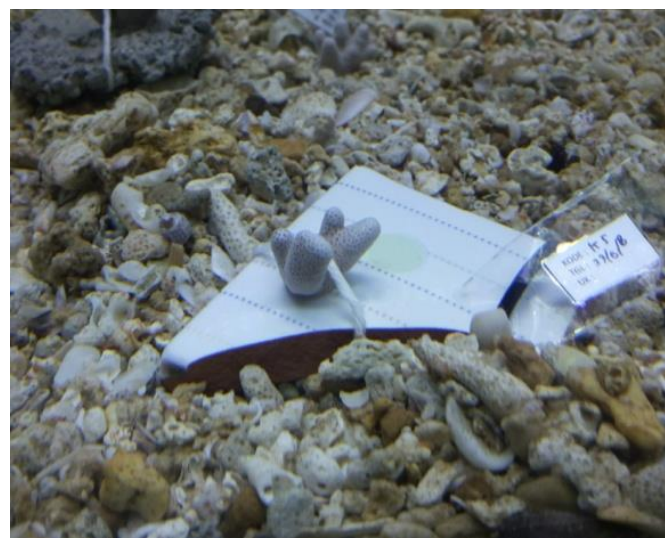

Substrat Keramik menempel pada substrat/media dampai kapitulum terluar/terpanjang (Prastiwi et al., 2012). Pengukuran panjang maupun lebar dilakukan setiap minggu selama tiga bulan.

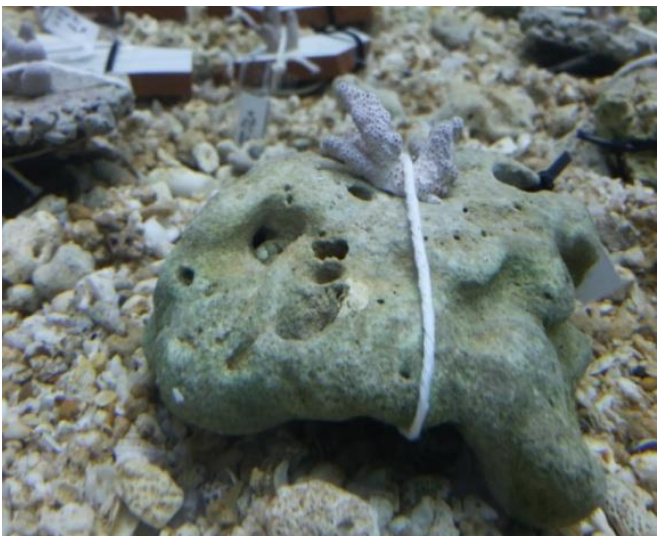

Substrat Semen

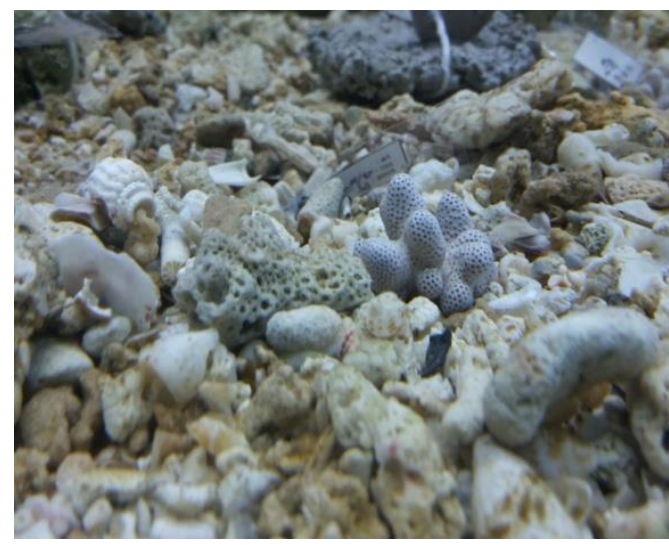

Substrat Rubble

Gambar 2. Jenis Substrat Untuk Karang Lunak Cladiella sp.

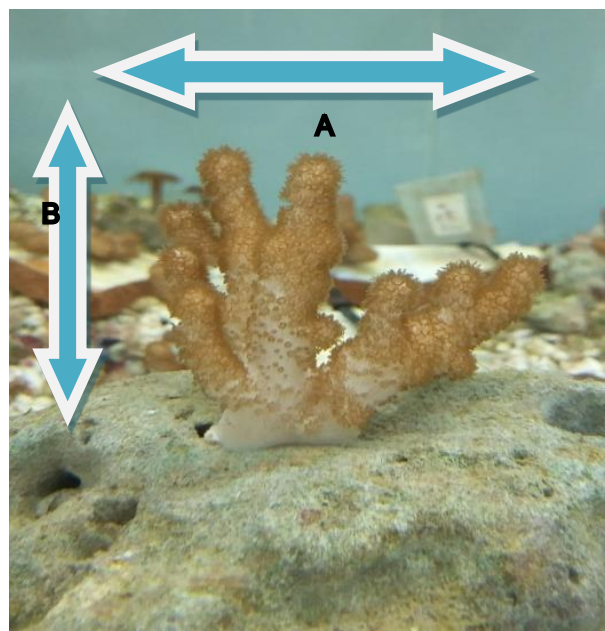

Gambar 3. Pengukuran Pada Fragmen Transplantasi Karang Lunak. (A) Lebar (B) Panjang 
Data yang dikumpulkan kemudian dianalisa menggunakan beberapa rumus seperti : tingkat kelangsungan hidup dilakukan dengan menghitung jumlah fragmen hasil pemotongan dan penempelan. Pengukuran dilakukan sampai pada akhir penelitian selama 3 bulan (12 minggu). Pengukuran dihitung dengan menggunakan rumus menurut Ricker (1975). Pertumbuhan dihitung untuk mengetahui seberapa besar karang lunak Cladiella sp. tumbuh selama penelitian 3 bulan (12 minggu). Perhitungan menggunakan rumus menurut Ricker (1975). Laju pertumbuhan dihitung menggunakan rumus menurut Zonneveld et al. (1991).

\section{HASIL DAN PEMBAHASAN}

Tingkat kelangsungan hidup karang selama penelitian yaitu $100 \%$. Sampel pada awal penelitian sebanyak 20 fragmen dan pada akhir penelitian selama 3 bulan (12 minggu) semua fragmen masih bertahan hidup dan tidak ada fragmen karang yang mati. Hal ini didukung oleh kualitas air yang baik dan terjaga (Tabel 2).

Tumbuhnya lumut menjadi faktor yang dapat membunuh karang lunak. Namun, akuarium selalu dibersihkan dari lumut yang tumbuh disekitar karang lunak. Biasanya setiap minggu dibersihkan menggunakan sikat gigi agar alga/lumut tidak menempel pada substrat/media penempelan karang lunak Cladiella sp. Dan air juga rutin diganti dalam setiap bulan sekali. Sehingga dengan terkontrolnya akuarium membantu karang lunak hidup sehat selama penelitian berlangsung.

Laju pertumbuhan mingguan karang lunak bervariasi. Nilai pertumbuhan panjang yang tertinggi yaitu pada $R$ (Rubble) dan terendah pada K (keramik). Pada Rubble nilai yang tinggi terjadi di minggu ke 2 sebesar $0,579 \mathrm{~cm} / \mathrm{ming} g u$ dan pada akhir penelitian sebesar $0,303 \mathrm{~cm} / \mathrm{minggu}$. Pada Keramik, nilai yang tinggi terjadi di minggu ke 3 sebesar $0,262 \mathrm{~cm} / \mathrm{ming} g u$ dan pada akhir penelitian sebesar 0,232 cm/minggu (Gambar 4).

Nilai pertumbuhan lebar yang paling tinggi terjadi pada $\mathrm{R}$ (Rubble) dan terendah pada K (Keramik). Pada Rubble, nilai yang tinggi terjadi di minggu ke 1 sebesar 1,111 $\mathrm{cm} /$ minggu dan akhir penelitian sebesar $0,296 \mathrm{~cm} / \mathrm{ming} g u$. Pada Keramik nilai yang tinggi terjadi di minggu ke $0,880 \mathrm{~cm} /$ minggu dan di akhir penelitian sebesar 0,089 $\mathrm{cm} /$ minggu (Gambar 5).

Pertumbuhan mingguan karang lunak yang bervariasi ini kemungkinan disebabkan oleh perbedaan substrat penempelan karang lunak. Pada setiap jenis substrat memiliki bentuk dan permukaan yang berbeda. Pada kegiatan tranplantasi memerlukan substrat yang kokoh untuk karang lunak (Suharsono et al., 2013). Karena pada saat diletakkan di di akuarium atau rak tranplantasi yang berada di alam tidak goyang atau lepas karena pengaruh arus ataupun ombak. Sehingga akan mempengaruhi penempelan dan pertumbuhan karang lunak itu sendiri.

Penelitian ini, didapatkan hasil yang tinggi pada substrat Rubble karena diduga pada Rubble pemulihan tingkat stres pada karang lunak Cladiella sp. lebih cepat dibandingkan dengan karang lunak Cladiella sp. pada substrat yang lainnya. Pada substrat Rubble tidak melalui proses penempelan dan pengikatan pada substrat yang dapat menyebabkan karang lunak stres karena tali dan membutuhkan waktu menempel pada substrat. Sehingga, pertumbuhannya lebih awal dibandingkan dengan karang lunak Cladiella sp. pada substrat yang lain dan menyebabkan nilai pertumbuhannya lebih tinggi/besar dibandingkan pada substrat yang lain.

Substrat Keramik yang mendapatkan nilai terendah dibandingkan dengan jenis substrat yang lainnya disebabkan oleh permukaan yang licin pada keramik. Jika dilihat dari hasil penelitian Kisworo et al., (2012) yang menunjukkan bahwa jenis substrat untuk menempelnya karang tidak berpengaruh terhadap penempelan karang. Namun, substrat yang memiliki kondisi permukaan yang kasar dan keras merupakan jenis substrat yang ideal sebagai tempat menempelnya karang. Sehingga pada permukaan Keramik yang licin akan sulit karang lunak Cladiella sp. untuk menempel secara sempurna sesuai dengan hasil penelitian Kisworo et al. (2012) pada karang 
keras Pocillopora damicormis. Sehingga, hal ini akan mempengaruhi pertumbuhan karang lunak sendiri dan mengakibatkan nilai pertumbuhan yang didapatkan rendah, dan pada dasarnya karang lunak akan menempel pada jenis substrat yang stabil (Prasetia 2012).

Hasil yang didapatkan pada akhir penelitian memiliki nilai yang rendah karena adanya pengaruh alga kompetitor yang hidup dalam akuarium. Hal ini juga sama dengan penelitian Prastiwi (2011) yang menyatakan bahwa hasil yang diperoleh bervariasi karena disebabkan oleh alga kompetitor yang tumbuh dan menggangu proses penyerapan cahaya matahari untuk proses fotosintesis.

Menurut hasil dari penelitian Haris (2001) pertumbuhan karang akan lebih baik dan cepat yang ditransplantasi di alam dibandingkan dengan hasil transplantasi di kolam/akuarium. Hal ini berkenaan dengan

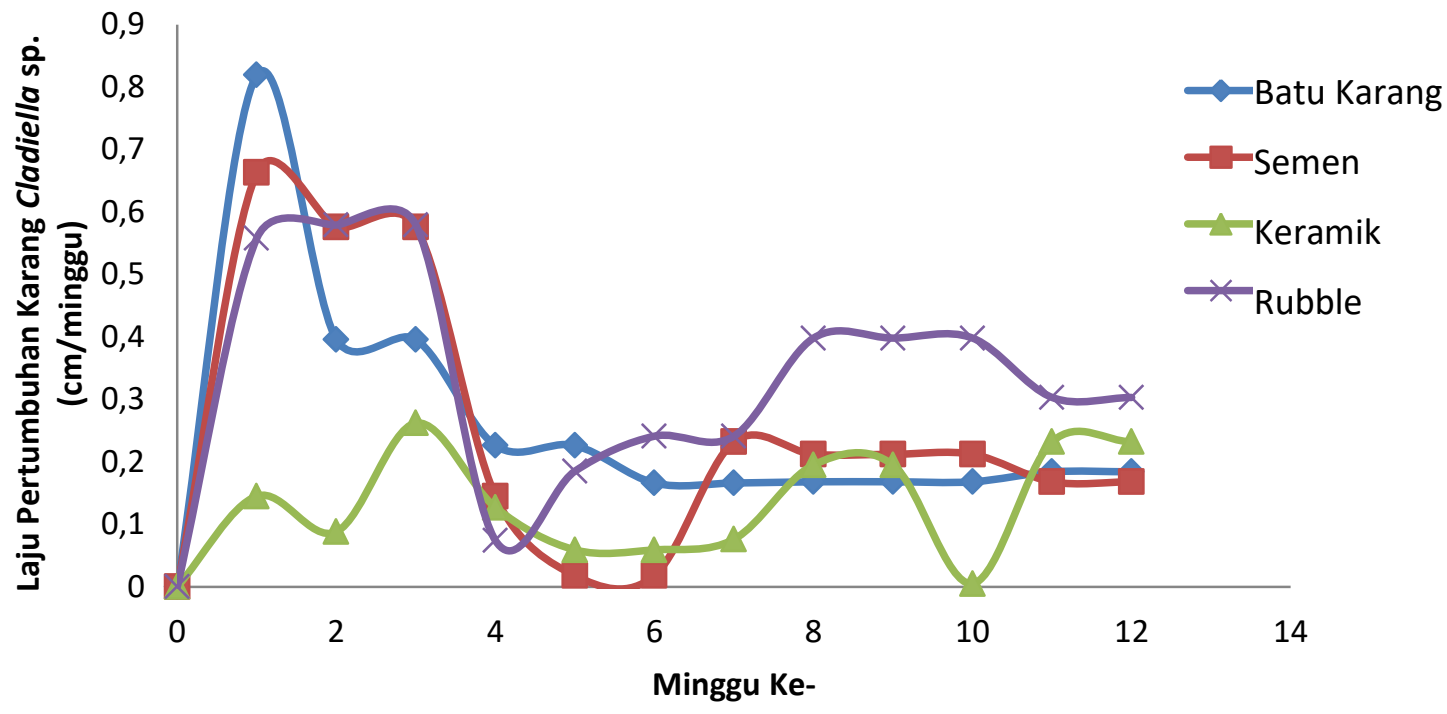

Gambar 4. Laju Pertumbuhan Panjang per Minggu Karang Lunak Cladiella sp. pada Jenis Substrat yang Berbeda

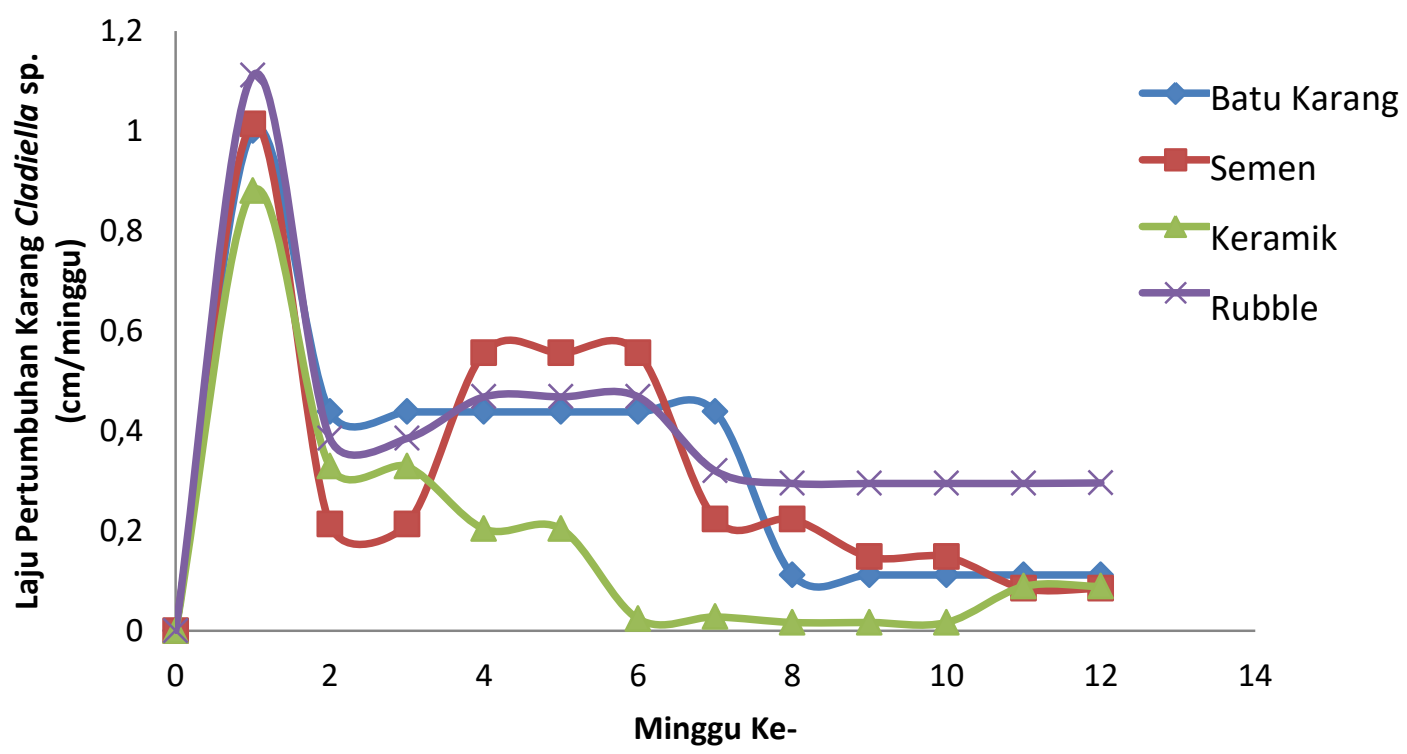

Gambar 5. Laju Pertumbuhan Lebar per Minggu Karang Lunak Cladiella sp. pada Jenis Substrat yang Berbeda 
nutrisi yang berada di alam lebih memenuhi terhadap perkembangan karang lunak dibandingkan dengan nutrisi yang berada di kolam/akuarium. Sehingga pada penelitian ini diberikan makanan/suplemen tambahan untuk mendukung pertumbuhan dari karang lunak Cladiella sp.

\section{Pertumbuhan Mutlak}

Pertumbuhan mutlak panjang Cladiella sp. pada masing-masing substrat terlihat bahwa pertumbuhan panjang yang baik terjadi pada substrat Rubble dengan nilai $2,338 \mathrm{~cm}$. Sedangkan nilai pertumbuhan panjang mutlak yang memiliki nilai rendah yaitu pada substrat Keramik dengan nilai 1,189 cm (Gambar 6). Pertumbuhan mutlak lebar Cladiella sp. pada masing-masing perlakuan terlihat bahwa pertumbuhan lebar yang baik terjadi pada jenis substrat penempel Rubble dengan nilai $2,875 \mathrm{~cm}$. Sedangkan pertumbuhan lebar yang nilainya rendah yaitu pada substrat Keramik dengan nilai $1,571 \mathrm{~cm}$ (Gambar 7).

Perbedaan yang terjadi kemungkinan diakibatkan oleh permukaan pada substrat/media. Karena kuat dugannya pada jenis substrat Rubble tidak ada perlakuan

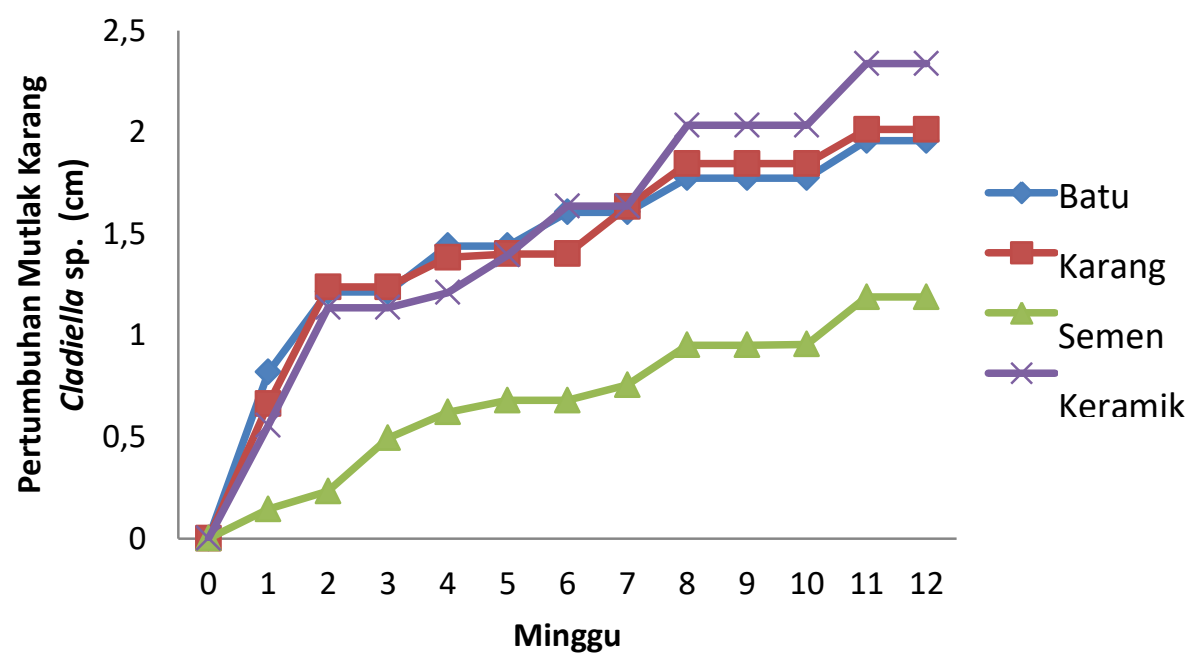

Gambar 6. Laju Pertumbuhan Panjang Mutlak Karang Lunak Cladiella sp. Pada Jenis Substrat Yang Berbeda

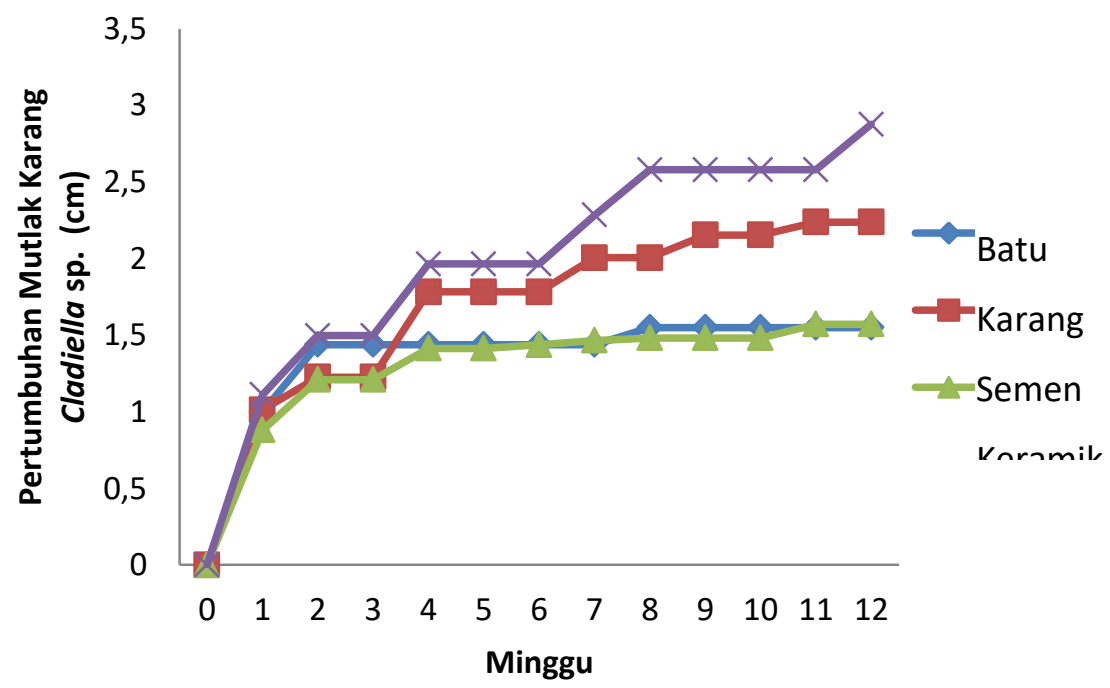

Gambar 7. Laju Pertumbuhan Lebar Mutlak Karang Lunak Cladiella sp. Pada Jenis Substrat Yang Berbeda 
penempelan menggunakan tali sehingga penyembuhan stresnya lebih cepat dibandingkan dengan jenis substrat yang lain. Sedangkan nilai terendah pada jenis substrat Keramik karena permukaannya licin, sehingga mempengaruhi pertumbuhan karang lunak. Sehingga Cladiella sp. yang menempel harus menyesuaikan diri dengan permukaan media penempelan dan hal itu membutuhkan waktu yang berbeda pada setiap media penempelan.

Jika dibandingkan dengan penelitian Prastiwi et al. (2012), laju pertumbuhan mutlak yang didapatkan tergantung pada arus dan cahaya matahari (sebagai kontrol). Sehingga nilai yang didapatkan lebih baik laju pertumbuhan panjang dibandingkan lebar. Namun, pada penelitian ini substratlah yang menjadi kontrol. Sehingga yang mempengaruhi laju pertubuhan antara panjang dan lebar adalah permukaan dari substrat sebagai tempet menempelnya karang lunak Cladiella sp. dan untuk faktor lingkungan hanya untuk mendukung pertumbuhan karang lunak dalam akuarium.

\section{Perbandingan Laju Pertumbuhan Karang Lunak Pada Berbagai Substrat}

Tidak ada perbedaan laju pertumbuhan karang lunak Cladiella sp baik panjang maupun lebar pada berbagai substrat yang berbeda (ANOVA, $p>0.05$ ). Hal ini diduga karena pada substrat/media untuk karang lunak menempel memiliki karakteristik yang hampir sama. Karakteristik substrat hampir sama yaitu menggunakan bahan yang keras dan bahan anorganik. Disamping dari bahannya, lingkungan dan kualitas air akuarium dalam kontrol yang sama. Sehingga tidak ada perbedaan pada penelitian.

Laju pertumbuhan panjang rata rata yang paling tinggi terjadi pada jenis substrat Rubble dengan rata-rata laju pertumbuhan panjang selama 3 bulan sebesar 0,195 $\mathrm{cm} /$ minggu (Gambar 7) dan laju pertumbuhan lebar rata-rata karang lunak terdapat pada substrat Rubble dengan ratarata $0,240 \mathrm{~cm} / \mathrm{ming}$ gu (Gambar 8). Pada substrat Rubble tidak ada perlakuan penempelan karena setelah karang lunak di potong langsung dibiarkan di atas rubble. Namun, pada perlakuan initerjadi kendala pada saat pengukuran. Sering kali sampel tersentuh oleh jangka sorong dan pada akhirya mengerut. Menurut Barton et al., (2015) bahwa karang lunak akan mengerutkan tubuhnya dengan mengeluarkan air dalam tubuhnya sebagai bentuk pertahanan ketika berada dalam keadaan terancam. Dan juga sampel seringkali berpindah tempat karena terkena arus yang ada pada akuarium. Laju

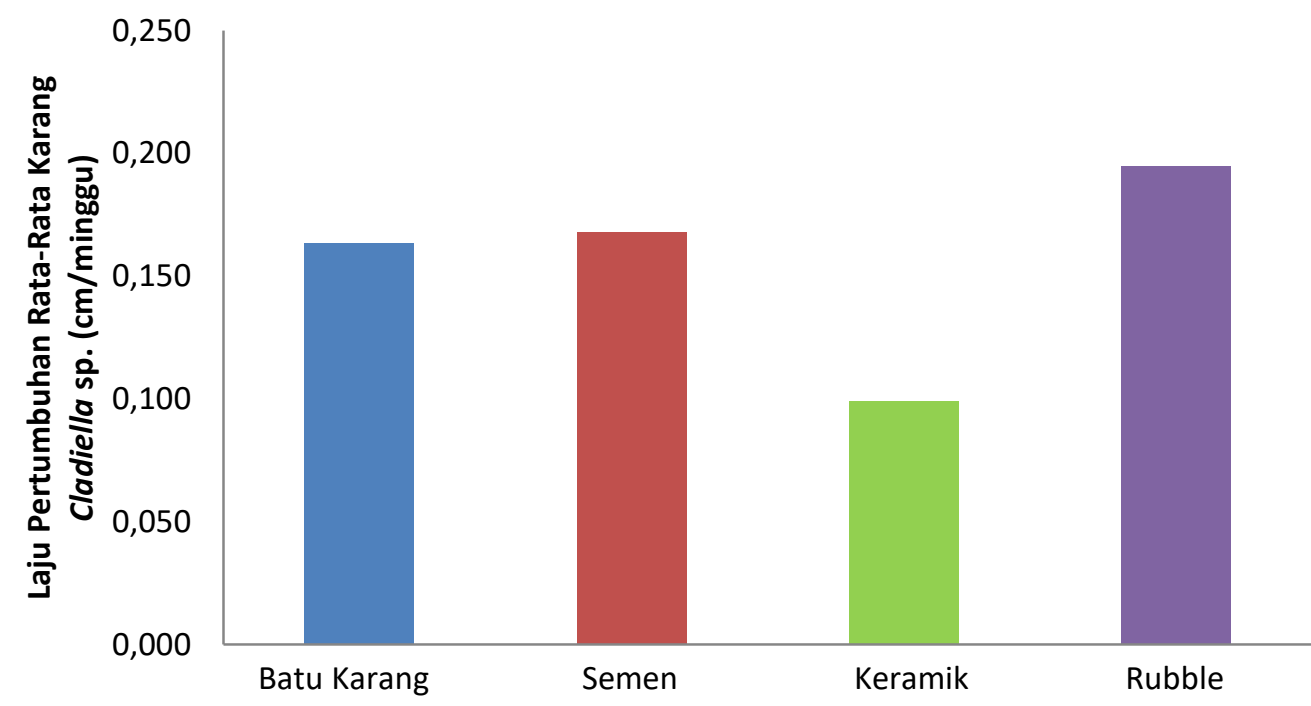

Gambar 7. Rata-Rata Laju Pertumbuhan Panjang Rata-Rata Karang Lunak Cladiella sp. Pada Jenis Substrat Yang Berbeda 
pertumbuhan panjang yang terendah terjadi pada substrat keramik dengan rata-rata laju pertumbuhan panjang selama 3 bulan sebesar 0,099 cm/minggu (Gambar 7) dan laju pertumbuhan lebar rata-rata karang lunak paling rendah pada substrat batu karang dengan rata-rata $0,129 \mathrm{~cm} /$ minggu (Gambar 8), diduga karena substrat Keramik memiliki permukaan yang licin mempengaruhi penempelan dan pertumbuhan karang lunak Cladiella sp.

Pada penelitian ini dilakukan pengambilan data kualitas air dalam akuarium sebagai data reaksi perubahan yang terjadi pada sampel karang lunak Cladiella sp. Semua parameter air masih dalam rentang kualitas air yang ditentukan dalam baku mutu untuk biota laut (KemenLH no 51 tahun 2004). Pengukuran kualitas air ini sangat penting untuk pertumbuhan karang lunak. Pada rekayasa habitat ini harus mampu menyamai dengan habitat asli dari karang lunak sehingga karang lunak dapat hidup dan tumbuh walaupun berada pada habitat yang direkayasa yaitu di dalam akuarium.

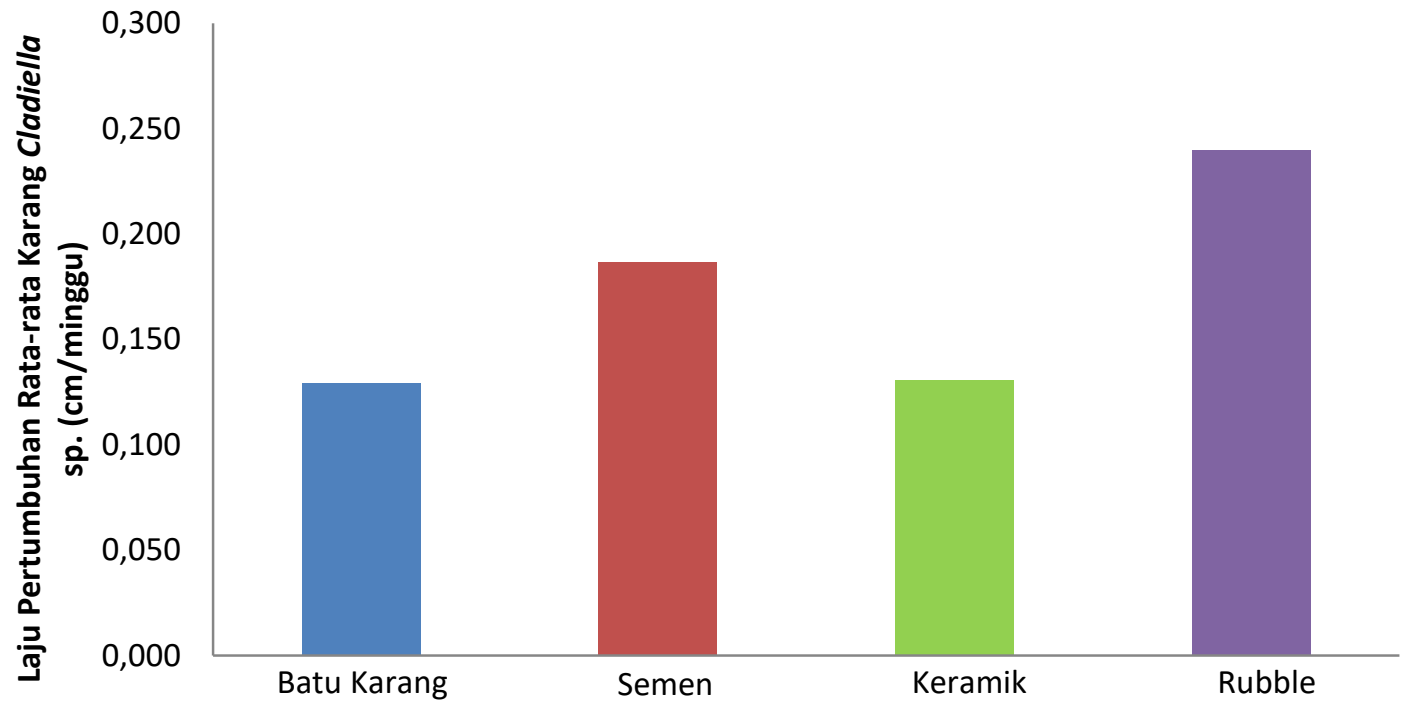

Gambar 8. Rata-Rata Laju Pertumbuhan Lebar Rata-Rata Karang Lunak Cladiella sp. Pada Jenis Substrat Yang Berbeda

Tabel 1. Pengukuran Kualitas Air Akuarium dan di Lapang Dibandingkan dengan Standar Baku Mutu

\begin{tabular}{|c|c|c|c|c|c|c|}
\hline Parameter & Satuan & $\begin{array}{c}\text { Nilai di Akuarium } \\
\text { Lab }\end{array}$ & Nilai Perairan & $\begin{array}{l}\text { Baku } \\
\text { Mutu }\end{array}$ & Sumber & Ket \\
\hline Suhu & ${ }^{\circ} \mathrm{C}$ & $26-28$ & 32 & $25-30$ & $\begin{array}{c}\text { Buckland et al., } \\
.(1999)\end{array}$ & Sesuai \\
\hline Salinitas & \%০ & $35-37$ & 30 & $27-40$ & $\begin{array}{c}\text { Nybakken } \\
\text { (1988) }\end{array}$ & Sesuai \\
\hline DO & $\mathrm{mg} / \mathrm{l}$ & $5-6$ & 6,9 & $>5$ & $\begin{array}{l}\text { KepMen LH } 51 \\
\text { th (2004) }\end{array}$ & Sesuai \\
\hline $\mathrm{pH}$ & - & $7-7,5$ & 8,50 & $7-8,5$ & $\begin{array}{c}\text { KepMen LH } 51 \\
\text { th (2004) }\end{array}$ & Sesuai \\
\hline
\end{tabular}




\section{KESIMPULAN}

Tingkat kelangsungan hidup pada akhir penelitian adalah $100 \%$ pada semua substrat. Sementara itu, laju pertumbuhan dan pertumbuhan mutlak karang lunak Cladiella sp. relatif bervariasi karena pengaruh perbedaan substrat yang berbeda, dengan laju pertumbuhan dan pertumbuhan mutlak tertinggi ditemukan pada substrat Rubble dan terendah ditemukan pada substrat keramik. Meskipun demikian, tidak ada perbedaan yang nyata pada laju pertumbuhan karang lunak Cladiella sp. pada substrat yang berbeda. Hasil penelitian ini mengimplikasikan bahwa meskipun tidak ada perbedaan yang nyata, substrat memberikan variasi pada laju pertumbuhan karang lunak. Oleh sebab itu, pada kegiatan transplantasi ataupun budidaya karang lunak, pemilihan substrat menjadi sangat penting, dan hasil penelitian menyarankan untuk menggunakan substrat rubble atau karang mati.

\section{DAFTAR PUSTAKA}

Bachtiar, I., Abrar, M., Budiyanto, A. 2012. Rekruitmen Karang Scleractinia di Perairan Pulau Lembata (Recruitment of Scleractinian Corals at Lembata Island Waters). IImu Kelautan: Indonesian Journal of Marine Sciences, 17(1):1-7.

Barton, J.A., Willis, B.L. \& Hutson, K.S. 2017. Coral propagation: a review of techniques for ornamental trade and reef restoration. Reviews in Aquaculture, 9(3):238-256.

Buckland, S.J., Ellis, H.K. \& Salter, R.T. 1999. Ambient Concentrations of Selected Organochlorines in Air. New Zealand: Ministry for the Environment. 9(3):238-256.

Haris, A. 2011. Transplantasi Karang Acroporidae Pada Substrat Alami. OmniAkuatika. 10(12):33-42

KemenLH (Kementerian Negara Lingkungan Hidup). 2004. Keputusan Menteri Negara Lingkungan Hidup No. 51 Tahun 2004 Tentang Baku Mutu Air Laut: Lampiran III Baku Mutu Air Laut untuk Biota Laut : Jakarta

Kisworo, H., Diah, P.W. \& Munasik. 2012. Studi Penempelan Juvenil Karang Pocillopora Damicornis Pada Jenis Substrat Kolektor
Dan Zona Terumbu Yang Berbeda Di Pulau Panjang, Kabupaten Jepara. Journal of Marine Research. 1 (1):129-136

Knittweis, L. \& Wolff, M. 2010. Live coral trade impacts on the mushroom coral Heliofungia actiniformis in Indonesia: Potential future management approaches. Biological Conservation, 143(11):2722-2729.

Prasetia, I.N.D. 2012. Rekrutmen Karang Di Kawasan Wisata Lovina. Jurnal Sains dan Teknologi. 1 (2): 61-72

Prastiwi, D.I., Soedharma, D. \& Subhan, B. 2012. Growth of transplanted soft corals Lobophytum strictum on recirculation system with different light conditions. Bonorowo Wetlands, 2(1):3139.

Ricker, W.E. 1975. Computation and Interpretation of Biological Statistics of Fish Populations. Department of Environment. Fisheries and Marine Service. Ottawa, Canada.

Rodrigues, I.G., Miguel, M.G. \& Mnif, W. 2019. A brief review on new naturally occurring cembranoid diterpene derivatives from the soft corals of the genera Sarcophyton, Sinularia, and Lobophytum since 2016. Molecules, 24(4): 781. doi : $10.3390 /$ molecules 24040781

Subhan, B., Soedharma, D., Arafat, D., Madduppa, H., Rahmawati, F., Ervinia, A., Bramandito, A., Khaerudi, D. \& Ghozali, A. T. 2012. Pengaruh Cahaya Terhadap Tingkat Kelangsungan Hidup Dan Pertumbuhan Karang Lunak Lobophytum Strictum (Octocoralia: Alcyonacea) Hasil Transplantasi Pada Sistem Resirkulasi. Jurnal Teknologi Perikanan dan Kelautan, 3(2):35-42.

Suharsono., Rikoh, M.S., Tri, A.H., Giyanto., Yosephine, T.A.B. \& Siti, S. 2013. Perkembangan Teknik Transplantasi Karang Di Indonesia. Pusat Penelitian Oseanografi-LIPI. Jakarta

Wijayanti, D.P., Charismawaty, A., Indrayanti, E. \& Trianto, A. 2017. Pertumbuhan Karang Lunak Sarcophyton sp. yang Dibudidayakan di Teluk Awur, Jepara. Buletin Oseanografi Marina, 6(1):61-68.

Zonneveld, N., Huisman, E.A. \& Boon, J.H. 1991. Prinsip-prinsip Budi Daya Ikan. Gramedia, Jakarta 